Kewa, M. G. A., Wijayanti, R.

Hubungan Latar Belakang Ekonomi Keluarga dan Dukungan Orang Tua terhadap Prestasi Belajar

Matematika

\title{
HUBUNGAN LATAR BELAKANG EKONOMI KELUARGA DAN DUKUNGAN ORANG TUA TERHADAP PRESTASI BELAJAR MATEMATIKA
}

\author{
Maria Geronsia Azi Kewa1, Rina Wijayanti² \\ 1,2 IKIP Budi Utomo Malang \\ onsimaria@gmail.com
}

\begin{abstract}
Abstrak
Prestasi belajar matematika adalah hasil belajar/kemampuan yang dicapai siswa selama dan setelah selesai mengikuti pelajaran matematika dimana hasilnya dinyatakan dalam bentuk angka atau simbol lainnya. Prestasi belajar dipengaruhi oleh beberapa faktor diantaranya latar belakang ekonomi keluarga dan dukungan orang tua. Penelitian ini adalah penelitian kuantitatif, populasi penelitian adalah seluruh siswa kelas VII SMPN 1 Boawae tahun ajaran 2017/2018, yang berjumlah 101 siswa. Pengambilan sampel menggunakan simple random sampling, dimana peneliti menetapkan $24 \%$ dari populasi untuk dipilih menjadi sampel, sehingga sampel penelitian berjumlah 24 siswa. Tahapan penelitian ini yaitu pengumpulan data menggunakan angket kemudian menganalisis data menggunakan pearson product moment correlation. Berdasarkan penelitian ini dapat disimpulkan ada hubungan yang tidak signifikan antara latar belakang ekonomi keluarga terhadap prestasi belajar matematika siswa karena nilai $r_{\text {hitung }}$ sebesar 0.242 lebih kecil $r_{\text {tabel }}$ pada taraf singnifikan $5 \%$ yaitu 0,404 dan ada hubungan antara dukungan orang tua terhadap prestasi belajar matematika siswa karena nilai $r_{\text {hitung }}$ sebesar 0.747 lebih besar dari $r_{\text {tabel }}$ pada taraf singnifikan $5 \%$ yaitu 0,404 serta terdapat hubungan secara bersama sama antara latar belakang ekonomi keluarga dan dukungan orang tua terhadap prestasi belajar matematika siswa karena nilai $\mathrm{F}_{\text {hitung }}$ sebesar 14,701 lebih besar dari $\mathrm{F}_{\text {tabel }}$ pada taraf singnifikan $5 \%$ yaitu 3,47 .
\end{abstract}

Kata kunci: ekonomi keluarga, dukungan orang tua, prestasi belajar

\begin{abstract}
Mathematics learning achievement is the learning outcome/ability achieved by students during and after completing mathematics lessons where the results are expressed in the form of numbers or other symbols. Learning achievement is influenced by several factors including family economic background and parental support. This research is quantitative research, the study population was all VII grade students of Boawae 1 Junior High School totaling 101 students. Sampling using simple random sampling, where researchers about $24 \%$ of the population to be selected as samples, so that the study sample amounted to 24 students. The stages of this research are data collection using a questionnaire then analyzing the data using Pearson product moment correlation. The data collection process uses questionnaire techniques. Research data were analyzed using Pearson
\end{abstract}


Kewa, M. G. A., Wijayanti, R.

Hubungan Latar Belakang Ekonomi Keluarga dan Dukungan Orang Tua terhadap Prestasi Belajar Matematika

product moment correlation. Based on this study, it can be concluded that There is an insignificant relationship between the family's economic background on the mathematics learning achievement because the value of $r_{\text {count }}$ is 0.242 smaller $r_{\text {table }}$ at a significant level of $5 \%$ that is 0.404 and there is a relationship between parental support for mathematics learning achievement because the $r_{\text {count }}$ of 0.747 is greater than rtable at a significant level of $5 \%$ which is 0.404 and there is a jointrelationship between the family's economic background and parental support for mathematics learning achievement because the Fcount value of 14.701 is greater than $\mathrm{F}_{\text {table }}$ at the $5 \%$ significance level of 3.47.

Keywords: family economics, parental support, learning achievement

\section{PENDAHULUAN}

Pendidikan merupakan cara untuk mencerdaskan bangsa. Pendidikan diselenggarakan untuk memberikan pencerahan dan sekaligus perubahan bagi peserta didik. Prestasi belajar adalah hasil belajar yang dicapai siswa selama mengikuti pelajaran pada periode tertentu dalam suatu lembaga pendidikan di mana hasilnya dinyatakan dalam bentuk angka atau simbol lainnya. Prestasi belajar matematika adalah hasil belajar/kemampuan yang dicapai siswa selama dan setelah selesai mengikuti pelajaran matematika. Prestasi belajar matematika dapat diukur secara langsung dengan test dan dapat dihitung hasilnya.

Berdasarkan data awal peneliti prestasi belajar matematika sebagian siswa VII SMP Negeri 1 Boawae masih rendah, walaupun tidak semua siswa mengalami hal tersebut. Karena setiap siswa memiliki kemampuan yang berbeda-beda. Untuk meningkatkan prestasi belajar matematika, pihak sekolah telah mengupayakan berbagai usaha seperti meningkatkan kemampuan akademis guru, kemampuan memberikan materi dan kemampuan berorientasi kepada siswa. Namun terkadang prestasi belajar matematika yang dicapai belum sesuai dengan yang diharapkan. Oleh karena itu, peneliti ingin mengetahui faktorfaktor yang dapat mempengaruhi prestasi belajar matematika pada siswa VII SMP Negeri 1 Boawae. Variabel independen yang digunakan dalam penelitian ini latar belakang ekonomi keluarga dan dukungan orang tua.

Menurut Sumardi, Hans dan Mulyannto ( 2005 ) kondisi sosial ekonomi adalah suatu kedudukan yang diatur secara sosial dan menempatkan seseorang pada posisi tertentu dalam masyarakat, pemberian posisi itu disertai pula dengan seperangkat hak dan kewajiban yang harus dimainkan oleh orang yang membawa status tersebut. Sementara W.S Winke 
Kewa, M. G. A., Wijayanti, R.

Hubungan Latar Belakang Ekonomi Keluarga dan Dukungan Orang Tua terhadap Prestasi Belajar Matematika

dalam (Basrowi, 2010) menyatakan bahwa pengertian status sosial ekonomi mempunyai makna suatu keadaan yang menunjukan pada kemampuan finansial keluarga dan perlengkapan material yang dimilki. Ada beberapa faktor yang dapat menentukan tinggi rendahnya keadaan sosial ekonomi keluarga di masyarakat, diantaranya jenis pekerjaan, tingkat pendidikan, tingkat pendapatan, pemilikan kekayaan, dan kondisi lingkungan tempat tingal.

Mulyanto dan Petter Hans dalam Menhard (2017) menyatakan tingkat pendapatan merupakan besarnya penghasilan yang diperoleh oleh satu keluarga baik bersumber dari penghasilan pokok, pekerjaan sampingan dan pendapatan lain yang berupa uang maupun barang. Menurut Sumardi dalam Basrowi (2010) untuk mengukur tingkat sosial ekonomi seseorang dari rumahnya, dapat dilihat dari: Status rumah yang ditempati, kondisi fisik bangunan, besarnya rumah yanng ditempati.

Faktor lain yang diteliti adalah dukungan dari orang tua. Dukungan menurut Kamus Besar Bahasa Indonesia (2008) adalah sesuatu yang didukung, sokongan; bantuan. Menurut Hasbullah dalam Fajriah (2012), orang tua adalah orang yang pertama dan utama yang bertanggung jawab terhadap kelangsungan hidup dan pendidikan anaknya. Dukungan orang tua mengacu pada dukungan sosial. Keluarga merupakan salah satu sumber dukungan sosial. Anak sangat membutuhkan bimbingan dan dukungan dari orangtua berupa dukungan moral dan dukungan material. Orang tua dapat memberikan dukungan moral kepada anak seperti perhatian terhadap pemenuhan kebutuhan psikis yang meliputi kasih sayang, keteladanan, bimbingan dan menanamkan rasa percaya diri. Sedangkan dukungan material adalah dukungan yang berupa pemenuhan fasilitas belajar anak.

Analisis korelasi merupakan metode yang bertujuan mencari hubungan antara variabel bebas/ ndependen dengan variabel terikat/dependen. Sehingga penelitian ini menggunakan Analisis Korelasi untuk mengetahui seberapa besar hubungan latar belakang ekonomi keluarga dan dukungan orang tua terhadap prestasi belajar matematika.

\section{METODE PENELITIAN}

Penelitian Hubungan Latar Belakan Ekonomi Keluarga dan dukungan orang tua terhadap prestasi belajar matematika siswa kelas VII SMP 1 Boawae menggunakan penelitian kuantitatif ex post facto. Menurut Sukardi (2012:15) bahwa penelitian ex-post facto merupakan 
Kewa, M. G. A., Wijayanti, R.

Hubungan Latar Belakang Ekonomi Keluarga dan Dukungan Orang Tua terhadap Prestasi Belajar Matematika

penelitian yang berhubungan dengan variabel yang telah terjadi dan tidak perlu memberikan perlakuan terhadap variabel yang diteliti. Variabel yang digunakan dalam penelitian ini yaitu prestasi belajar matematika siswa kelas VII SMP 1 Boawae sebagai variabel dependen dan variabel independennya adalah latar belakang ekonomi keluarga $\left(\mathrm{X}_{1}\right)$ dan dukungan orang tua siswa kelas VII SMP 1 Boawae $\left(\mathrm{X}_{2}\right)$.

Penelitian ini dilakukan di SMP Negeri 1 Boawae yang berada di desa Raja, kecamatan Boawae, kabupaten Nagekeo, Nusa Tenggara Timur pada pertengahan bulan Februari sampai dengan pertengahan bulan April 2018. Populasi penelitian ini adalah seluruh siswa kelas VII SMP 1 Boawae tahun ajaran 2017-2018 yang berjumlah 101. Sampel dalam penelitian ini menggunakan simple random sampling dengan menetapkan 24\% dari populasi untuk dipilih menjadi sampel.

Pengumpulan data dalam penelitian ini menggunakan angket dan dokumentasi. Indikator yang dipakai dalam mengukur latar belakang ekonomi keluarga siswa kelas VII SMP 1 Boawae adalah tingkat pendidikan orang tua, jenis pekerjaan orang tua, pendapatan orang tua, pemilikan barang berharga dan jenis tempat tinggal. Sedangkan indikator dukungan orang tua adalah dukungan emosional, dukungan instrumental, dukungan informasi dan dukungan penilaian.

Teknik analisis data yang digunakan dalam penelitian Hubungan Latar Belakan Ekonomi Keluarga dan dukungan orang tua terhadap prestasi belajar matematika siswa kelas VII SMP 1 Boawae adalah analisis korelasi tunggal atau parsial dan korelasi ganda (multiple corelation). Analisis korelasi tunggal atau parsial digunakan untuk menghitung nilai koefisien korelasi antara masing-masing variabel bebas dengan variabel terikat. Menurut Arikunto (Sugiyono, 2016: 259), rumus yang digunakan untuk mencari koefisien korelasi tunggal atau parsial adalah:

$$
r x . y=\frac{\sum x y}{\sqrt{\cdot\left(\sum x^{2}\right) \cdot\left(\sum y^{2}\right)}}
$$

Keterangan:

rx.y = koefisien korelasi antara variabel bebas dengan variabel terikat

$\sum \mathrm{x}^{2}=$ jumlah kuadrat variabel bebas

$\sum \mathrm{y}^{2}=$ jumlah kuadrat variabel terikat

$\sum \mathrm{xy}=$ jumlah perkalian setiap kasus variabel

Hipotesis yang digunakan adalah sebagai berikut. Ho: tidak ada hubungan yang positif antara latar belakang ekonomi keluarga dengan prestasi belajar matematika siswa siswa kelas VII SMP 1 Boawae. Ha: ada hubungan yang positif antara latar belakang 
Kewa, M. G. A., Wijayanti, R.

Hubungan Latar Belakang Ekonomi Keluarga dan Dukungan Orang Tua terhadap Prestasi Belajar

ekonomi keluarga dengan prestasi belajar matematika siswa siswa kelas VII SMP 1 Boawae.

Pengujian hipotesis dilakukan dengan membandingkan nilai rhitung dengan $\mathrm{r}_{\text {tabel }}$ pada taraf signifikansi 5\%. Menggunakan taraf signifikansi $5 \%$ artinya peneliti memiliki kepercayaan terhadap data sebesar 95\% dan meyakini tingkat kesalahannya hanya sebesar 5\%. Jika rhitung < rtabel, maka Ho diterima $(\alpha<5 \%)$, yang berarti tidak ada hubungan antara latar belakang ekonomi keluarga dengan prestasi belajar matematika siswa kelas VII SMP N 1 Boawae. Jika rhitung $\geq$ rtabel, maka Ha diterima ( $\alpha \geq 5 \%)$, yang berarti ada hubungan antara latar belakang ekonomi keluarga dengan prestasi belajar matematika siswa kelas VII SMP N 1 Boawae. Ho: tidak hubungan yang positif antara dukungan orang tua dengan prestasi belajar matematika siswa kelas VII SMP N 1 Boawae. Ha: ada hubungan yang positif antara dukungan orang tua dengan prestasi belajar matematika siswa kelas VII SMP N 1 Boawae.

Jika rhitung $<$ rtabel, maka Ho diterima $(\alpha<5 \%)$, yang berarti tidak ada hubungan antara dukungan orang tua dengan prestasi belajar matematika siswa kelas VII SMP N 1 Boawae. Jika rhitung $\geq$ rtabel, maka Ha diterima ( $\alpha \geq$ $5 \%$ ), yang berarti ada hubungan antara dukungan orang tua dengan prestasi belajar matematika siswa kelas VII SMP N 1 Boawae.

Analisis korelasi ganda bertujuan menghitung nilai koefisien korelasi seluruh variabel bebas secara bersama-sama dengan variabel terikat. Menurut Sudjana (Sugiyono, 2016: 266), rumus untuk menghitung koefisien korelasi ganda adalah:

$R_{y \cdot x_{i} \cdot x_{2}}=\sqrt{\frac{r_{y x_{1}^{2}+} r_{y x_{2}^{2}-2 r y x_{1} \cdot r y x_{2} \cdot r x_{1} x_{2}}}{1-r_{x_{1} x_{2}^{2}}}}$

Keterangan :

$R_{Y_{X_{1}} X_{2}}=$ Korelasi antara variabel $\mathrm{X} 1$ dengan X2 secara bersamasama dengan variabel $Y$

ryx $_{1}=$ =orelasi Product Moment antara $\mathrm{X} 1$ dengan $\mathrm{Y}$ ryx $_{2}$ =Korelasi Product Moment antara X2 dengan $\mathrm{Y}$ $r y x_{1} x_{2}=$ Korelasi Product Moment antara X1 dengan X2

Adapun untuk menguji hipotesis, maka setelah menghitung koefisien $\mathrm{Ry}_{(123)}$ harus dicari nilai Fhitung. Menurut (Sugiyono, 2016: 266) rumus yang digunakan untuk mencari nilai Fhitung adalah:

$$
F_{h}=\frac{R^{2} / k}{\left(1-R^{2}\right) /(n-k-1)}
$$

Keterangan:

$\mathrm{R}=$ Koefisien Korelasi Ganda

$\mathrm{k}=$ Jumlah Variabel Independen

$\mathrm{n}=$ Jumlah Anggota Sampel

Uji hipotesis yang digunakan adalah 
Kewa, M. G. A., Wijayanti, R.

Hubungan Latar Belakang Ekonomi Keluarga dan Dukungan Orang Tua terhadap Prestasi Belajar Matematika

Ha: ada hubungan yang positif antara latar belakang ekonomi keluarga dan dukungan orang tua dengan prestasi belajar matematika siswa kelas VII SMP N 1 Boawae.

Ho: tidak ada hubungan yang positif antara latar belakang ekonomi keluarga dan dukungan orang tua dengan prestasi belajar matematika siswa kelas VII SMP N 1 Boawae.

Pengujian hipotesis dilakukan dengan membandingkan nilai $F_{\text {hitung }}$ dengan $F_{\text {tabel }}$ pada taraf signifikansi 0.05 atau $5 \%$ dan derajat kebebasan (db) N-k-1. Menggunakan taraf signifikansi 5\% artinya peneliti memiliki tingkat kepercayaan terhadap kebenaran data sebesar 95\% dan meyakini tingkat kesalahannya hanya sebesar 5\%. Jika $F_{\text {hitung }}<$ Ftabel, maka Ho diterima $(\alpha<5 \%)$, yang berarti tidak ada hubungan secara simultan antara latar belakang ekonomi keluarga dan dukungan orang tua dengan prestasi belajar matematika siswa kelas VII SMPN 1 Boawae. Jika Fhitung $\geq$ Ftabel, maka Ha diterima ( $\alpha$ $\geq 5 \%$ ), yang berarti ada hubungan secara simultan antara latar belakang ekonomi keluarga dan dukungan orang tua dengan prestasi belajar matematika siswa kelas VII SMPN 1 Boawae. Adapun interpretasi koefisien korelasinya disajikan dalam Tabel 1 sebagai berikut.

Tabel 1 Interpretasi Koefisien Korelasi

\begin{tabular}{|c|c|}
\hline Interval Koefisien & Tingkat Hubungan \\
\hline $0,00-0,199$ & Sangat Rendah \\
\hline $0,20-0,399$ & Rendah \\
\hline $0,40-0,599$ & Sedang \\
\hline $0,60-0,799$ & Kuat \\
\hline $0,80-1,000$ & Sangat kuat \\
\hline
\end{tabular}

(Sugiyono, 2017: 257)

\section{HASIL DAN PEMBAHASAN}

Sebelum dilakukan Analisis Korelasi, peneliti melakukan Uji Normalitas dahulu menggunakan Uji Kolmogorov Smirnov. Dari hasil perhitungan uji normalitas yang telah dilakukan disimpulkan bahwa nilai signifikansinya $>0,05$ $(0,330>0,05)$, sehingga data pada penelitian Hubungan Latar Belakan Ekonomi Keluarga dan dukungan orang tua terhadap prestasi belajar matematika siswa kelas VII SMP 1 Boawae berdistribusi normal.

\section{Hubungan latar belakang ekonomi keluarga dengan prestasi belajar matematika siswa}

Berdasarkan hasil penelitian bahwa ada hubungan yang tidak singinifan antara latar belakang 
Kewa, M. G. A., Wijayanti, R.

Hubungan Latar Belakang Ekonomi Keluarga dan Dukungan Orang Tua terhadap Prestasi Belajar Matematika

ekonomi keluagra dengan prestasi belajar matematika siswa, hal ini nampak dari hasil penelitian yang menunjukan bahwa rhitung sebesar 0.239 dan rtabel pada taraf singnifikan 5\% adalah 0,404 maka rhitung $<$ rtabel. Dari sini terlihat bahwa latar belakang ekonomi keluarga yang tinggi belum tentu menghasilkan prestasi belajar matematika yang tinggi dan latar belakang ekonomi keluarga rendah

\section{Hubungan dukungan orang tua dengan prestasi belajar matematika siswa.}

Berdasarkan hasil penelitian bahwa ada hubungan antara dukungan orang tua dengan prestasi belajar matematika siswa, hal ini nampak dari hasil penelitian yang menunjukan bahwa rhitung sebesar 0.747 dan rabel pada taraf singnifikan 5\% adalah 0,404 maka rhitung > rtabel. Ini berarti semakin tinggi dukungan yang diberikan orang tua pada anak maka semakin baik juga prestasi belajar yang diperolehnya. Sebaliknya semakin rendah dukungan orang tua pada anak maka semakin rendah prestasi belajarnya.

\begin{tabular}{llr} 
Hubungan latar belakang & \multicolumn{2}{c}{ lan } \\
ekonomi keluarga & dan \\
dukungan orang orang tua \\
terhadap prestasi belajar \\
matematika siswa.
\end{tabular}

Berdasarkan hasil penelitian bahwa ada hubungan secara bersama sama antara latar belakang ekonomi keluarga dan dukungan orang tua terhadap prestasi belajar matematika siswa. Hal ini nampak dari hasil penelitian yang menunjukan bahwa Fhitung sebesar 14,50 dan $\mathrm{F}_{\text {tabel }}$ pada taraf singnifikan $5 \%$ adalah 3,47 maka $F_{\text {hitung }}>F_{\text {tabel. }}$. Dari hasil perhitungan terlihat bahwa latar belakang ekonomi keluarga dan dukungan orang tua berhubungan erat dalam meningkatkan prestasi belajar matematika siswa.

Siswa yang mempunyai latar belakang ekonomi keluarga yang tinggi dengan kebutuhan belajar terpenuhi namun jika tidak diimbangi dengan dukungan moril dari orang tua maka akan berpengaruh terhadap prestasi belajar siswa yang kurang maksimal. Sebaliknya siswa dengan latar belakang ekonomi keluarga yang pas-pasan dan kebutuhan belajarnya kurang terpenuhi namum jika diimbangi dengan dukungan moril dari orang tua maka prestasi belajar siswa akan lebih meningkat.

\section{KESIMPULAN DAN SARAN}

Berdasarkan hasil penelitian yang diperoleh dapat disimpulkan bahwa:

1. Ada hubungan tetapi tidak singnifikan antara latar belakang ekonomi keluarga terhadap prestasi belajar matematika siswa kelas VII SMPN 1 Boawae. 
Kewa, M. G. A., Wijayanti, R.

Hubungan Latar Belakang Ekonomi Keluarga dan Dukungan Orang Tua terhadap Prestasi Belajar Matematika

2. Ada hubungan yang signifikan antara dukungan orang tua terhadap prestasi belajar matematika siswa kelas VII SMPN 1 Boawae.

3. Ada hubungan yang signifikan antara latar belakang ekonomi keluarga dan dukungan orang tua terhadap prestasi belajar matematika siswa kelas VII SMPN 1 Boawae.

Saran bagi peneliti selanjutnya, krena sampel dalam penelitian ini sedikit maka peneliti selanjutnya diharapkan mengambil populasi dan sampel dengan jumlah yang lebih banyak agar hasil yang diperoleh lebih bagus lagi.

\section{DAFTAR PUSTAKA}

Basrowi \& Siti Juariyah. 2010. Analisis Kondisi Sosial Ekonomi Dan Tingkat Pendidikan Masyarakat Desa Srigading, Kecamatan Labuhan Maringgai, Kabupaten Lampung Timur. Jurnal Ekonomi Dan Pendidikan, 7 (1), (Online), journal.uny.ac.id. Diakses 20 Januari 2018.

Departemen Pendidikan Nasional. 2008. Kamus Basar Bahasa Indonesia Pusat Bahasa. Jakarta: PT Gramedia Pusat Utama.

Depdiknas. 2003. Undang-Undang RI No.20 Tahun 2003 Tentang Sistem Pendidikan Nasional.
Desmita. 2009. Psikologi Perkembangan Peserta Didik. Bandung: PT Remaja Rosdakarya.

Dian Anita. 2015. Hubungan antara Status Sosial Ekonomi Orang Tua dan Motivasi Berprestasi dengan Prestasi Belajar Siswa Kelas XI Kompetensi Keahlian Administrasi Perkantoran SMK Muhammadiyah 2 Bantul Tahun Ajaran 2014/2015. Skripsi. UNY: Yogyakarta

Dimyati \& Mudjiono. 2009. Belajar dan Pembelajaran. Jakarta: Rineka Cipta.

Hardiyanto. 2017. Pengaruh Ekonomi Terhadap Pendidikan Dan Peran Pendidikan Membangun Ekonomi. Jurnal Pendidikan Islam, 6, Januari-Juni.

Menhard. 2017. Pengaruh Pendapatan Orang Tua Dan Status Sosial Terhadap Minat Melanjutkan Pendidikan Ke Perguruan Tinggi. (STIE) Mahaputra Riau. Jurnal Wira Ekonomi Mikroskil, 7 (1).

Sugihartono, dkk . 2007. Psikologi Pendidikan. Yogyakarta: UNY Press.

Sumardi, Mulyanto \& Hans-Dieter Evers, 2005. Kemiskinan dan Kebutuhan Pokok. Jakarta: CV. Rajawali.

Watoni, Mohammad. 2017. Pengaruh Status Sosial, 
Kewa, M. G. A., Wijayanti, R.

Hubungan Latar Belakang Ekonomi Keluarga dan Dukungan Orang Tua terhadap Prestasi Belajar Matematika

Tingkat Pendidikan Orang Tua Dan Kondisi Ekonomi Terhadap Motivasi Melanjutkan Pendidikan Ke Perguruan Tinggi Pada Siswa Ma Palapa Nusantara. Jurnal Pendidikan Guru Madrasah Ibtidaiyah, 2 (1). (Online), http://ejournal.kopertais4. or.id/. Diakses 18 Januari 2018. 